\title{
Haemophilia B presenting with bilateral cephalhaematomas
}

\author{
*Niraj Kumar Dipak ${ }^{1}$, Ruchi Nimish Nanavati ${ }^{1}$, Nand Kishore Kabra ${ }^{1}$
}

Sri Lanka Journal of Child Health, 2017; 46(2): 178-179

DOI: http://dx.doi.org/10.4038/sljch.v46i2.8278

(Key words: Haemophilia B, cephalhaematoma, neonate)

\section{Introduction}

Haemophilia is the commonest inherited bleeding disorder to present in the neonatal age group ${ }^{1}$. Recent studies suggest that $15-33 \%$ of newborns with inherited bleeding disorders initially present with bleeding manifestations in the neonatal period $^{2}$. Factor IX deficiency (Haemophilia B, Christmas disease) is an $\mathrm{X}$-linked recessive coagulation disorder. Its prevalence is estimated to be around 1 in 30,000 males. In most neonates with haemophilia $\mathrm{B}$, initial presentation of spontaneous bleeding may be in form of skin bleeding, extracranial haemorrhage $(\mathrm{ECH})$ or intracranial haemorrhage $(\mathrm{ICH})^{3,4,5}$. Other spontaneous bleeding events reported sporadically were gastrointestinal bleeding 6 , bleeding from spleen $^{4}$ as well as occult bleeding like adrenal and liver haematomas ${ }^{7}$. As far as we are aware there are no reports in the literature of haemophilia A or B presenting with bilateral cephalhaematomas.

\section{Case report}

A male child, born to a 24 year old fourth gravida mother, was admitted to our institution on the $9^{\text {th }}$ day of life with gradually increasing swellings over both parietal regions, noticed from the $3^{\text {rd }}$ day of life (Figure 1). The mother has 3 other healthy children, a 5 year old boy, a 4 year old girl and an 8 month old girl respectively. The mother had a full term normal vaginal delivery with an uneventful antenatal period. Birth weight was $2.5 \mathrm{~kg}$. The baby cried immediately after birth and the Apgar score was 9 at one minute. Vitamin $\mathrm{K}$ was given to the baby at birth. Examination revealed bilaterally symmetrical soft, fluctuant swellings measuring $3.5-4 \mathrm{~cm}$ in diameter over the parietal regions

${ }^{1}$ Department of Neonatology, Seth GS Medical College and KEM Hospital, Acharya Donde Marg, Parel, Mumbai 400012, Maharashtra, India

*Correspondence: neonatalfundas@gmail.com

(Received on 28 January 2016: Accepted after revision on 17 March 2016)

The authors declare that there are no conflicts of interest

Personal funding was used in formulating the article.

Open Access Article published under the Creative

Commons Attribution CC-BY (c) ()

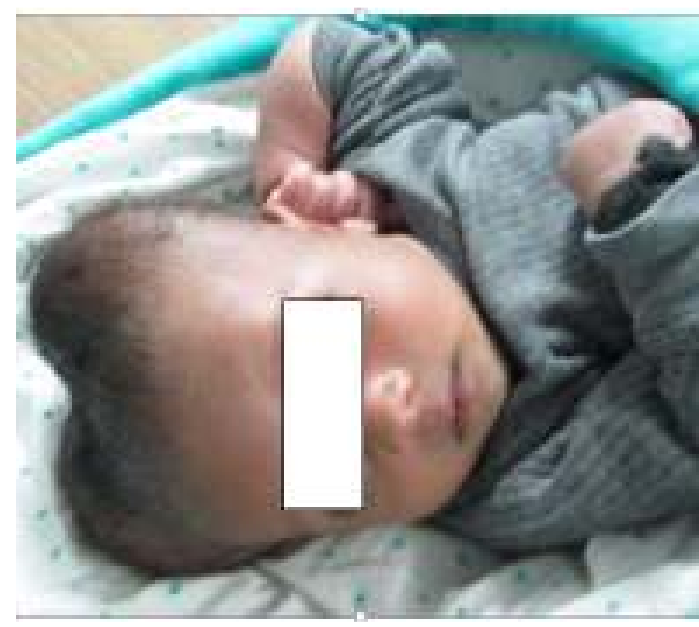

Figure 1: Bilateral cephalhaematomas

*Permission given by parents to publish photograph

suggestive of cephalhaematomas. The child was pale but haemodynamically stable. There was no evidence of bleeding from any other site. X-ray skull did not show an underlying linear skull fracture and there was no evidence of intraventricular / intra-parenchymal haemorrhage on ultrasonography of the cranium. There was no family history of bleeding tendencies.

The haemoglobin level was $9.8 \mathrm{~g} \%$, packed cell volume $31 \%$, total leucocyte count $9,500 / \mathrm{cu} \mathrm{mm}$ and platelet count $280,000 / \mathrm{cu} \mathrm{mm}$. The prothrombin time was 12.6 seconds, activated partial thromboplastin time (aPTT) 130 seconds and the thrombin clotting time 20.4 seconds. In view of the prolonged aPTT, factor assay was performed. Factor VIII was $58.7 \%$ and factor IX was less than $1 \%$ indicating a severe deficiency of factor IX. Factor IX concentrate transfusion was given $(40 \mathrm{IU} / \mathrm{kg}$ ) every third day till 21 days of admission. He was discharged at 1 month of age and was advised to come for follow-up.

\section{Discussion}

Early diagnosis of haemophilia in neonates is very important for appropriate management, early prophylaxis, parental education and for minimizing the risk of mortality. Timely diagnosis of haemophilia in neonates poses a challenge in cases where there is no family history. The difficulties in diagnosis are mainly due to failure to identify the 
presence of abnormal bleeding in neonates, which is often different from that typically observed in older children with haemophilia. In addition, diagnostic investigations are complicated by physiological differences in the neonatal haemostatic system ${ }^{2}$. Both intracranial haemorrhage (ICH) and extracranial haemorrhage $(\mathrm{ECH})$ are observed in neonates with haemophilia and the incidence of $\mathrm{ICH}$ in neonates with severe haemophilia is estimated to be $1-4 \%{ }^{8,9}$. In a literature review, ICH was more common than $\mathrm{ECH}$ and the most frequent site of haemorrhage was subdural ${ }^{9}$. Both $\mathrm{ECH}$ and $\mathrm{ICH}$ are associated with a significant risk of mortality as a consequence of massive blood loss even in apparently normal infants ${ }^{10}$. Anaemia and jaundice are the most frequent clinical manifestations in cases of ICH and ECH, followed by shock and hypotension ${ }^{9}$. However, in our case the newborn presented with bilateral cephalhaematomas without severe pallor, icterus or shock. The significance of ECH should not be underestimated as it can be lifethreatening due to massive blood loss resulting in hypovolaemic shock and carries a significant risk of mortality even in apparently normal neonates ${ }^{10}$. In neonates presenting with massive cephalhaematomas without shock, anaemia, trauma or instrumentation at the time of delivery, the possibility of bleeding disorders should be borne in mind.

\section{Acknowledgements}

Authors thank the Dean, Seth GS Medical College and KEM Hospital, Mumbai for permitting them to publish the manuscript.

\section{References}

1. Smith P S. Congenital coagulation protein deficiencies in the perinatal period. Seminars in Perinatology 1990; 14:38492.

PMid: 2287954

2. Chalmers EA. Neonatal coagulation problems. Archives of Disease in Childhood Fetal and Neonatal Edition 2004; 89:F475-8. http://dx.doi.org/10.1136/adc.2004.05009 6

PMid: 15499133 PMCid: PMC1721785

3. Baujard C, Gouyet L, Murat I. Diagnosis and anaesthesia management of haemophilia during the neonatal period. Pediatric Anaesthesia 1998; 8(3):245 PMid: 9608971

4. Johnson-Robbins LA, Porter JC, Horgan MJ. Splenic rupture in a newborn with haemophilia A: a case report with review of literature. Clinical Paediatrics 1999; 38:117-96.

http://dx.doi.org/10.1177/0009922899038 00210

5. Ries M, Klinge J, Rauch R, Chen C, Deeg $\mathrm{KH}$. Spontaneous subdural haematoma in a 18 day old male newborn infant with severe haemophilia A. Clinical Paediatrics 1998;210:120-4.

6. Conway JH, Hilgartner MW. Initial presentations of paediatric haemophilia. Archives of Pediatrics Adolescent Medicine 1994; 6:589-94.

http://dx.doi.org/10.1001/archpedi.1994.0 2170060043007

7. Le Pommelet C, Durand P, Laurian Y, Devictor D. Haemophilia A: two cases showing unusual features at birth. Hemophilia 1998; 4(2):122-5. http://dx.doi.org/10.1046/j.13652516.1998 $.00170 . x$

8. Ljung R. The optimal mode of delivery for the haemophilia carrier expecting an affected infant is vaginal delivery. Haemophilia 2010; 16:415-9.

PMid: 19925629

9. Kulkarni R, Lusher JM. Intracranial and extracranial haemorrhages in newborns with haemophilia. Journal of Pediatric Hematology/Oncology 1999; 21:289-95. http://dx.doi.org/10.1097/0004342619990 7000-00009

PMid: 10445891

10. Plauche W C. Subgaleal haematoma. A complication of instrumental delivery. Journal of the American Medical Association 1980; 244: 1597-8.

http://dx.doi.org/10.1001/jama.1980.0331 0140055031 